\title{
Pengaruh Dosis Pupuk N, P, dan K terhadap Kecernaan Secara In Vitro Rumput Gajah (Pennisetum purpureum) cv. Taiwan yang di Inokulasi CMA Glomus manihotis pada Lahan Bekas Tambang Batubara
}

\section{The Influence of the dosage of N,P, K fertilizers on in vitro digestibility of Pennisetum purporeum cv Taiwan innoculated by Glomus manihotis on former coal mine land}

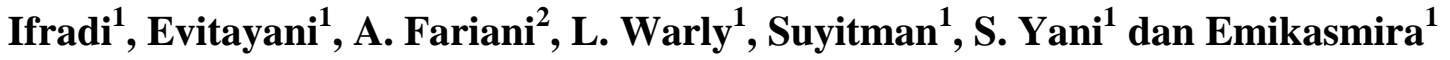 \\ ${ }^{1}$ Fakultas Peternakan Universitas Andalas \\ Kampus Unand Limau Manis Padang, 25163 \\ ${ }^{2}$ Fakultas Pertanian Universitas Sriwijaya, Palembang \\ e-mail: evita28229@yahoo.com
}

(Diterima: 23 Juli 2011, Disetujui: 20 Desember 2011)

\begin{abstract}
This objective of the research was to investigated the digestibility of dry matter, organic matter and crude protein of elephant grass $\mathrm{cv}$. Taiwan by in vitro technique. The method of research was using a Random Design Group with 5 treatments and 4 replications. The treatment $A(100 \% N, P$ and $K$ without $C M A)$, treatment $B(100 \% N, P$, and $K+10 g r$ of $C M A)$, treatment $C(75 \% N, P$, and $K+10 g r$ of $C M A)$, treatment $D(50 \% \mathrm{~N}, P$, and $K+10 \mathrm{gr}$ of $C M A)$ and treatment $E(25 \% \mathrm{~N}, P$, and $K+10 \mathrm{gr}$ of CMA), respectively. The results of the research showed that the effects of dry matter, organic matter and crude protein digestibility were not significantly $(P<0.05)$ different between the treatments. The dry matter digestibility of elephant grass cv. Taiwan ranged from $53.47 \%$ to $57.72 \%$, organic matter digestibility ranged from $57.66 \%$ to $63.75 \%$, and crude protein digestibility ranged from $65.67 \%$ to $70.70 \%$, respectively. It could be concluded that the given of $25 \%$ of $N, P$, and $K+10$ gram of CMA glomus manihotis was better the digestibility on dry matter, organic matter and crude protein. Therefore, it means that the same value with fertilizer N, P, and K $100 \%$ without CMA.
\end{abstract}

Keywords: Elephant Grass (Pennisetum purpureum), CMA Glomus Manihotis, N, P and K, in vitro

\section{PENDAHULUAN}

Faktor yang utama untuk mendapatkan produksi yang optimal dari ternak khususnya ternak ruminansia adalah faktor pakan hijauan di samping faktor lainnya. Pakan hijauan terdiri atas: rumput, leguminosa, daun-daunan, dan sisa hasil pertanian. Pemenuhan akan kebutuhan rumput belum terjamin ketersediaannya setiap saat. Untuk itu perlu ditanam suatu jenis rumput yang mempunyai produksi tinggi dan berkualitas tinggi seperti Rumput Gajah agar kebutuhan ternak tersebut terpenuhi. Rumput Gajah adalah jenis rumput unggul yang mempunyai nilai produktivitas tinggi, membentuk rumpun dengan pertumbuhan tegak, dan mudah dikembangkan secara vegetatif.
Lahan untuk usaha penanaman hijauan makanan ternak saat ini mengalami kendala. Hal ini disebabkan lahan-lahan yang subur telah dimanfaatkan untuk menanam tanaman pangan maupun perkebunan. Kondisi ini mengakibatkan lahan untuk penanaman rumput semakin berkurang. Salah satu usaha untuk mencari lahan penanaman rumput adalah lahan bekas penambangan batubara. Batubara mengandung berbagai mineral dan unsur anorganik yang berbentuk ion terlarut dalam air rembesan dan keberadaannya melimpah pada endapan batubara muda. Perombakan mineral dan bahan anorganik serta racun akan menimbulkan pencemaran air. Penggunaan CMA yang dikombinasikan dengan pemupukan $(\mathrm{N}, \mathrm{P}$, dan $\mathrm{K})$ yang efisien merupakan suatu alternatif untuk memecahkan masalah tersebut. Pemberian dosis pupuk $\mathrm{N}$ 
(urea) $200 \mathrm{~kg} / \mathrm{ha}, \mathrm{P}$ (SP-36) $150 \mathrm{~kg} / \mathrm{ha}$, dan $\mathrm{K}$ (KCl) $100 \mathrm{~kg} / \mathrm{ha}$ dapat meningkatkan produksi dan kandungan gizi dari Rumput Gajah. Aplikasi Cendawan Mikoriza Arbuskula (CMA) pada lahan bekas penambangan batubara diharapkan mampu mempercepat pertumbuhan tanaman rumput dengan beberapa sifat positif yang dimilikinya. Tanaman yang bermikoriza umumnya tumbuh lebih baik pada lahan kritis dibandingkan dengan tanaman yang lainnya karena mikoriza secara efektif dapat meningkatkan penyerapan unsur hara mikro. Hal ini menyebabkan pemakaian pupuk lebih hemat dibandingkan dengan tanaman tanpa aplikasi mikoriza.

Kecernaan zat-zat makanan merupakan salah satu ukuran dalam menentukan suatu kualitas bahan makanan ternak, disamping komposisi kimia, produk fermentasi, dan pabilitasnya. Untuk mempelajari daya cerna dan fermentasi, metode yang berhasil digunakan secara luas yaitu teknik in vitro. Dalam teknik in vitro contoh makanan diinkubasikan dalam cairan rumen (sebagai sumber mikroba rumen) yang ditambah dengan cairan penyangga (buffer). Keuntungan in vitro menurut Church (1979) dapat dilakukan secara tepat dalam waktu yang singkat dan biaya yang ringan, karena jumlah sampel yang digunakan sedikit, kondisi mudah dikontrol dan dapat mengevaluasi lebih dari satu macam kecernaan bahan dalam waktu yang sama. Oleh sebab itu, berdasarkan hal diatas maka penulis tertarik melakukan penelitian yang berjudul Pengaruh dosis pupuk $\mathrm{N}, \mathrm{P}$ dan $\mathrm{K}$ terhadap kecernaan secara in vitro rumput Gajah (Pennisetum purpureum) cv Taiwan yang diinokulasi CMA Pada lahan bekas tambang batubara.

\section{METODE}

\section{Materi Penelitian}

Bahan dan Perlengkapan: lahan yang digunakan untuk penanaman hijauan makanan ternak adalah lahan kritis bekas penambangan batubara di Kota Sawahlunto (Sumatera Barat) dengan luas lahan $298,2 \mathrm{~m}^{2}(21 \times 14,2 \mathrm{~m})$ yang digunakan sebagai medium tumbuh.
Bibit Rumput Gajah (Pennisetum purpureum) cv. Taiwan dalam bentuk stek. Pupuk kandang, pupuk urea, SP-36, $\mathrm{KCl}$, rumen buatan untuk metode rumen secara in vitro dan peralatan laboratorium untuk menganalisis kandungan bahan organik (BO), bahan kering (BK), dan protein kasar (PK) dari sampel rumput.

\section{Metode Penelitian}

Metode yang dipakai dalam penelitian ini adalah metode eksperimen menggunakan Rancangan Acak Kelompok (RAK) dengan 5 macam perlakuan dan 4 ulangan (kelompok). Bertindak sebagai kelompok adalah kemiringan lahan. CMA akan diinokulasi dengan dosis 10 gram/rumpun, sedangkan pupuk N, P, dan $\mathrm{K}$ akan diberikan pada dosis $100 \%$, $75 \%$, $50 \%$, dan $25 \%$ dari yang direkomendasikan.

Dosis pupuk N, P, dan K dan inokulasi CMA adalah sebagai berikut :

$\mathrm{A}=100 \%$ pupuk N, P, dan K tanpa CMA

$\mathrm{B}=100 \%$ pupuk N, P, dan K + CMA Glomus manihotis

$\mathrm{C}=75 \%$ pupuk N, P, dan K + CMA Glomus manihotis

$\mathrm{D}=50 \%$ pupuk N, P, dan $\mathrm{K}+\mathrm{CMA}$ Glomus manihotis

$\mathrm{E}=25 \%$ pupuk N, P, dan $\mathrm{K}+\mathrm{CMA}$ Glomus manihotis

Dosis pupuk N, P, dan K dapat dilihat pada Tabel 1 .

Dosis $100 \% \mathrm{~N}, \mathrm{P}$, dan $\mathrm{K}$ rekomendasi berdasarkan hasil penelitian dari Fedrial (2005) yaitu $200 \mathrm{~kg} / \mathrm{ha}$ untuk urea, $150 \mathrm{~kg} / \mathrm{ha}$ untuk SP-36, dan $100 \mathrm{~kg}$ untuk KCl. CMA diinokulasikan dengan dosis $10 \mathrm{~g}$.

Model Rancangan Acak Kelompok adalah sebagai berikut :

$$
\mathrm{Yij}=\mu+\tau \mathrm{i}+\beta \mathrm{j}+\Sigma \mathrm{ij}
$$

Perbedaan antar nilai tengah perlakuan dilanjutkan dengan pengujian DMRT (Duncan's Multiple Range Test) (Steel and Torrie, 1991). 
Tabel 1 : Jenis dan Dosis Pupuk pada Tiap Perlakuan

\begin{tabular}{cccccc}
\hline \multirow{2}{*}{ JENIS PUPUK } & \multicolumn{5}{c}{ DOSIS PERLAKUAN (gram/Plot) } \\
\cline { 2 - 6 } & $\mathrm{A}$ & $\mathrm{B}$ & $\mathrm{C}$ & $\mathrm{D}$ & $\mathrm{E}$ \\
\hline Urea & 200 & 200 & 150 & 100 & 50 \\
SP-36 & 150 & 150 & 112,5 & 75 & 37,2 \\
$\mathrm{KCl}$ & 100 & 100 & 75 & 50 & 22 \\
\hline
\end{tabular}

\section{Pelaksanaan Penelitian}

1. Persiapan in vitro. Cairan rumen yang diambil langsung dmasukkan ke dalam termos agar temperatur tetap $39^{\circ} \mathrm{C}$, mikroba dalam cairan rumen tidak mati dan kondisi tetap anaerob. Cairan rumen disaring dengan menggunakan 4 lapisan chesscloth dan dibuat larutan McDouglass. Semua bahan dilarutkan menjadi satu liter larutan aquades. Larutan buffer disiapkan sehari sebelum fermentasi, kemudian diletakkan didalam shaker water bath pada suhu $39^{\circ} \mathrm{C}$ dan gas $\mathrm{CO}_{2}$ dialirkan selama 30-60 detik untuk mempertahankan kondisi anaerob, dan pHnya diukur mendekati 7 dengan menggunakan $\mathrm{NaOH} 20 \%$ atau $\mathrm{H}_{3} \mathrm{PO}_{4}$ $20 \%$. Inokulum dipersiapkan dengan mencampur 4 bagian buffer dengan 1 bagian cairan rumen.

2. Pelaksanaan Penentuan Kecernaan secara in vitro di Laboratorium. Fermentasi in vitro dilaksanakan berdasarkan metode oleh Tilley dan Terry (1963). Tabung fermentasi yang berisi 5 gram sampel dan blanko (hanya berisi inokulum) diletakkan dalam shaker waterbath, masing-masing tabung ditambahkan $200 \mathrm{ml}$ inokulum dan $50 \mathrm{ml}$ cairan rumen yang dialiri gas $\mathrm{CO}_{2}$ selama 30-60 detik. Fermentasi dilaksanakan dalam shaker waterbath pada suhu $39^{\circ} \mathrm{C}$ dengan kecepatan goyangan 95 per menit dengan waktu inkubasi 48 jam. Setelah waktu inkubasi selesai ditambahkan dua tetes $\mathrm{HgCl}_{2}$ untuk membunuh mikroba. Sampel yang telah difermentasi kemudian dikeringkan dalam oven $105^{\circ} \mathrm{C}$ selama lebih kurang 24 jam untuk menentukan kandungan bahan kering.

\section{Penentuan Kandungan dan Kecernaan} Bahan Kering, bahan organik dan protein. Untuk mendapatkan kandungan bahan kering terlebih dahulu dilakukan analisis kadar air dengan cara : 1-2 gram sampel ditimbang (a) dan dimasukkan ke dalam cawan porselin yang telah diketahui beratnya (b), lalu dipanaskan dalam oven $135^{\circ} \mathrm{C}$ selama lebih kurang 3 jam. Setelah itu didinginkan dalam desikator selama 30 menit dan ditimbang beratnya (c), berat pengurangannya merupakan berat air dalam bahan.

$$
\operatorname{Kadar} \operatorname{Air}(\%)=\frac{(\mathrm{a}+\mathrm{b})-\mathrm{c}}{\mathrm{a}} \quad \mathrm{X} \quad 100 \%
$$

Kecernaan bahan kering dihitung dengan rumus :

$\mathrm{KCBK}=\mathrm{BK}$ awal-$-(\mathrm{BK}$ residu $+\mathrm{BK}$ Blanko $) \times 100 \%$

$$
\text { BK awal }
$$

Untuk mendapatkan bahan organik terlebih dahulu dilakukan analisis kadar abu dengan cara sebagai berikut: Cawan yang sudah bersih dikeringkan dalam oven pada temperatur $105-110^{\circ} \mathrm{C}$ selama 1 jam. Kemudian didinginkan dalam desikator selama kurang lebih 1 jam dan ditimbang beratnya. Timbang sampel 1 gram masukkan ke dalam cawan kemudian dibakar dengan nyala Bunsen sampai habis asapnya. Setelah itu baru dipijarkan dalam tanur listrik pada temperatur $600^{\circ} \mathrm{C}$ selama lebih kurang 3 jam sampai berwarna putih. Setelah dipijarkan lalu diturunkan suhunya menjadi $120^{\circ} \mathrm{C}$ (dimasukkan dalam oven). Kemudian dimasukkan ke dalam desikator selama 1 jam. Setelah dingin cawan bersama abu ditimbang dengan timbangan analitik. 
Kadar Abu $(\%)=\frac{(\mathrm{z}-\mathrm{x})}{\mathrm{y}} \times 100 \%$

Kadar Bahan Organik $(\%)=100 \%$ - kadar abu

Kecernaan Bahan Organik (KCBO) dihitung dengan rumus :

$\operatorname{KCBO}(\%)=$

$\underline{\mathrm{BO} \text { awal }-(\mathrm{BO} \text { residu + BO Blanko }) \text { x 100\% }}$ BO awal

Kandungan protein kasar dengan menggunakan metode Kjeldahl:

\section{a. Destruksi}

Sampel ditimbang sebanyak 1 gram, lalu dimasukkan ke dalam labu kjeldahl, tambahkan 1 gram katalisator selenium dan diberi $20 \mathrm{ml} \mathrm{H}_{2} \mathrm{SO}_{4}$ teknis, kemudian didestruksi di almari asam mulai dengan api kecil dan dikocok sewaktu sampai larutan berwarna hijau jernih, diencerkan didalam labu kjeldahl ke dalam labu ukur $250 \mathrm{ml}$ dengan aquades.

\section{b. Destilasi}

Sampel dipipet $25 \mathrm{ml}$ masukkan ke dalam labu destilasi tambah $150 \mathrm{ml}$ aquades tambah $20 \mathrm{ml} \mathrm{NaOH} \mathrm{40 \% .} \mathrm{Hasil} \mathrm{ditampung}$ dengan $10 \mathrm{ml}$ indikator boraks dalam erlenmeyer $250 \mathrm{ml}$. Penyulingan dilakukan dengan hati-hati, penyulingan dianggap selesai bila volumenya mencapai $100 \mathrm{ml}$. Penyulingan dihentikan dan dibilas dengan aquades ke dalam labu penampung. Hasil penguapan selanjutnya dititrasi dengan $\mathrm{H}_{2} \mathrm{SO}_{4}$ $0,1 \mathrm{~N}$ sampai terjadi perubahan warna. Nilai blanko diperoleh dengan titrasi indikator tanpa menggunakan sampel. Kandungan Protein Kasar (PK) sampel dihitung dengan rumus sebagai berikut :

Kadar PK =

$\frac{(\mathrm{Y}-\mathrm{X}) \times \mathrm{N} \mathrm{NaOH} \times 0.014 \times \mathrm{C} 6.25 \times 10}{\mathrm{Z}} \times 100 \%$

Maka untuk menghitung Kecernaan Protein Kasar (KCPK) adalah :

$\operatorname{KCPK}(\%)=\underline{\text { PK awal }-\mathrm{PK} \text { residu }} \times 100 \%$

PK awal

\section{HASIL DAN PEMBAHASAN}

\section{Pengaruh Perlakuan terhadap Kecernaan Bahan Kering (BK)}

Rataan kecernaan bahan kering Rumput Gajah cv. Taiwan berkisar dari 53,47 sampai dengan 57,72\% (Tabel 2). Berdasarkan hasil analisis keragaman menunjukkan bahwa perlakuan memberikan pengaruh yang tidak berbeda nyata $(\mathrm{P}>0,05)$ terhadap kecernaan bahan kering. Hal ini disebabkan adanya kemampuan CMA yang dapat membantu penyerapan unsur-unsur hara dalam tanah sehingga pengurangan dosis pupuk $\mathrm{N}, \mathrm{P}$, dan $\mathrm{K}$ yang diberikan menghasilkan produksi dan kandungan gizi relatif sama pada masingmasing perlakuan

CMA dapat meningkatkan serapan unsur-unsur hara, karena akar tanaman yang diinfeksi dengan CMA dapat menerobos sampai ke pori-pori mikro tanah, dengan adanya enzim phosphatase yang dihasilkan oleh hifa-hifa CMA, yang dapat secara kimia merombak dan menyerap unsur hara $\mathrm{P}$ (Husin, 2002). Dalam penelitian ini penggunaan CMA Glomus manihotis dapat mengurangi dosis pupuk N, P, dan K sampai 75\% menghasilkan Kecernaan Bahan Kering yang tidak berbeda nyata dengan perlakuan A. Hasil ini tidak berbeda jauh dengan hasil penelitian Ningsih (2007) bahwa kecernaan bahan kering Rumput Gajah (Pennisetum purpureum) cv. Taiwan pada tanah ultisol berkisar dari $64,72 \%$ sampai dengan $65,33 \%$.

Rendahnya kecernaan bahan kering pada perlakuan A (tanpa CMA) dibandingkan dengan perlakuan $\mathrm{B}, \mathrm{C}, \mathrm{D}$, dan $\mathrm{E}$ (dengan CMA), hal ini disebabkan berbedanya unsurunsur hara (sedikit unsur hara) yang terserap oleh tanaman, sebab pada perlakuan A tidak ada inokulasi CMA, adanya CMA berfungsi untuk membantu penyerapan zat-zat hara melalui hifa-hifa yang terbentuk. Dengan banyaknya unsur hara yang diserap oleh tanaman, maka fotosintesis akan meningkat sehingga makin banyak pula karbohidrat yang dihasilkan oleh tanaman yang akan membantu pembentukan batang dan daun (Buckman dan Brady, 1982; Lakitan, 1993). Selanjutnya 
Read (1999) menjelaskan bahwa sistem simbiosis mutualisme terjadi karena cendawan mikoriza yang hidup di dalam sel akar mendapat sebagian karbon hasil fotosintesis tanaman dan tanaman akan mendapatkan hara atau keuntungan lain dari cendawan mikoriza.

\section{Pengaruh Perlakuan terhadap Kecernaan Bahan Organik (BO)}

Rataan kecernaan bahan organik $57,66 \%$ sampai dengan 63,75\% (Tabel 2). Hasil analisis keragaman menunjukkan bahwa perlakuan memberikan pengaruh yang tidak berbeda nyata $(\mathrm{P}>0,05)$ terhadap kecernaan bahan organik Rumput Gajah (Pennisetum purpureum) cv. Taiwan. Berbeda tidak nyatanya kecernaan bahan organik masingmasing perlakuan disebabkan kandungan gizi masing - masing perlakuan relatif sama (Lampiran 6). Kandungan bahan organik masing-masing perlakuan berkisar antara $81,04 \%-89,22 \%$. Kandungan gizi ini tidak berbeda jauh dengan penelitian Suyitman (2003) bahwa kandungan bahan organik Rumput Gajah (Pennisetum purpureum) cv. Taiwan berkisar antara 84,20\% - 89,90\%. Kandungan gizi yang relatif sama akan menghasilkan kecernaan bahan organik yang juga relatif sama. Kandungan gizi yang relatif sama dari masing-masing perlakuan disebabkan adanya kemampuan Cendawan Mikoriza Arbuskula (CMA) membantu meningkatkan penyerapan nutrien dalam tanah sehingga komposisi zat makanan yang terkandung dalam bahan organik relatif sama walaupun terjadi pengurangan dosis pupuk $\mathrm{N}, \mathrm{P}$, dan $\mathrm{K}$ sampai $75 \%$. Sesuai dengan pendapat Suhardi (1994) bahwa hubungan asosiasi antara akar tanaman dan hifa jamur dapat meningkatkan kemampuan CMA dalam penyerapan nutrien dalam tanah sehingga nilai gizi rumput menjadi tinggi.

Terbungkusnya permukaan akar oleh mikoriza, menyebabkan akar terhindar dari serangan hama dan penyakit, infeksi patogen terhambat. Selain itu mikoriza juga menggunakan semua kelebihan karbohidrat dan eksudat akar lainnya, sehingga tercipta lingkungan yang tidak cocok untuk patogen. Di lain pihak cendawan mikoriza ada yang dapat mematikan patogen, mengurangi penyakit busuk akar. Demikian pula mikoriza telah dilaporkan dapat mengurangi serangan nematoda (Anas dan Santoso, 1992).

Kecernaan bahan organik berkolerasi positif dengan kecernaan bahan kering. Kecernaan bahan kering yang tidak berbeda nyata akan mengakibatkan kecernaan bahan organik tidak berbeda nyata juga. Hal ini disebabkan bahan kering disusun oleh bahan organik dan anorganik. Bahan organik disusun oleh karbohidrat, protein kasar, lemak, dan vitamin, sementara anorganik (abu) disusun oleh $\mathrm{Ca}, \mathrm{P}$, dan lain sebagainya. Sutardi 1980 menyatakan bahwa dengan peningkatan bahan kering menyebabkan kecernaan bahan organik juga meningkat karena kecernaan bahan kering berbanding lurus dengan kecernaan bahan organik. Bahan kering tercerna sebagian besar terdiri dari bahan organik (protein, lemak, dan karbohidrat) dapat dicerna. Hasil ini tidak berbeda jauh dengan hasil penelitian Ningsih (2007) bahwa kecernaan bahan organik Rumput Gajah (Pennisetum purpureum) cv. Taiwan pada tanah ultisol berkisar dari $63,07 \%$ sampai dengan $63,97 \%$.

\section{Pengaruh Perlakuan terhadap Kecernaan Protein Kasar (PK)}

Rataan kecernaan protein kasar antara $65,67 \%-70,70 \%$ (Tabel 2). Hasil analisis keragaman menunjukkan bahwa perlakuan memberikan pengaruh yang tidak berbeda nyata $(\mathrm{P}>0,05)$ terhadap kandungan gizi protein kasar Rumput Gajah (Pennisetum purpureum) cv. Taiwan. Kandungan gizi protein kasar Rumput Gajah cv. Taiwan berkisar antara $10,31 \%$ sampai dengan $15,16 \%$. Hasil penelitian ini tidak berbeda jauh dengan penelitian Suyitman dkk. (2003) bahwa kandungan gizi protein kasar Rumput Gajah cv. Taiwan berkisar antara 13,00\% sampai dengan $14,00 \%$. Kandungan gizi yang relatif sama pada masing-masing perlakuan akan menghasilkan kecernaan protein kasar juga relatif sama yang diberi pupuk $\mathrm{N}, \mathrm{P}$, dan $\mathrm{K}$ yang diinokulasi dengan CMA Glomus 
Tabel 2. Rataan Kecernaan Bahan Kering, Bahan Organik, dan Protein Kasar

\begin{tabular}{cccc}
\hline Perlakuan & $\begin{array}{c}\text { Kecernaan Bahan } \\
\text { Kering }(\%)\end{array}$ & $\begin{array}{c}\text { Kecernaan Bahan } \\
\text { Organik }(\%)\end{array}$ & $\begin{array}{c}\text { Kecernaan Protein } \\
\text { Kasar }(\%)\end{array}$ \\
\hline A & 53,47 & 57,66 & 67,98 \\
B & 54,89 & 59,00 & 65,37 \\
C & 57,72 & 60,55 & 66,88 \\
D & 54,80 & 62,15 & 67,85 \\
E & 56,90 & 63,75 & 70,70 \\
\hline SE & 3,2 & 2,15 & 1,85 \\
\hline
\end{tabular}

Keterangan: Antar perlakuan menunjukan pengaruh yang berbeda tidak nyata $(\mathrm{P}>0,05)$;

SE : Standar Error

manihotis karena CMA memiliki peran yang signifikan dalam membantu penyerapan zat nutrisi khususnya pada tanah yang kurang subur. De La Cruz (1981) menyatakan bahwa unsur hara yang diserap meningkat dengan adanya mikoriza antara lain $\mathrm{N}, \mathrm{P}$, dan $\mathrm{K}$ masing-masing 50\%, 46\%, dan 38\%. Tisdale dan Nelson (1975) menyatakan bahwa N adalah unsur hara utama dalam pembentukan protein makanan, oleh sebab itu dibutuhkan unsur hara $\mathrm{N}$ yang lebih banyak untuk meningkatkan kandungan protein kasar.

Menurut Husin (2002), bahwa tumbuhan yang bermikoriza dapat menyerap fospor, nitrogen, dan kalium yang lebih banyak dibandingkan dengan yang tidak bermikoriza pada substrat yang sama. Menurut Setiadi (1994) juga membuktikan bahwa CMA mampu mengurangi atau menghemat kira-kira $50 \%$ kebutuhan fospor, $40 \%$ nitrogen, dan 25\% kalium, meningkatkan efesiensi pemupukan, karena CMA dapat memperpanjang dan memperluas jangkauan akar terhadap penyerapan unsur hara di dalam tanah, terutama unsur fospor.

Hasil ini tidak berbeda jauh dengan hasil penelitian Ningsih (2007) bahwa kecernaan protein kasar Rumput Gajah (Pennisetum purpureum) cv. Taiwan pada tanah ultisol berkisar dari $64,74 \%$ sampai dengan $71,09 \%$.

\section{KESIMPULAN}

Berdasarkan hasil penelitian dapat disimpulkan bahwa pemberian $25 \%$ pupuk $\mathrm{N}$, $\mathrm{P}$, dan $\mathrm{K}+\mathrm{CMA}$ Glomus manihotis 10 gram/rumpun menghasilkan kecernaan bahan kering, bahan organik, dan protein kasar relatif sama dengan pemupukan N, P, dan K 100\% tanpa CMA.

\section{DAFTAR PUSTAKA}

Anas, 1. dan D.A. Santoso.1992.Mikoriza vesikular asbuskular dalam S. Harran dan N. Ansori. Bioteknologi Pertanian 2. Pusat Antar Universitas Pangan dan Gizi-Instistut Pertanian Bogor. Bogor. Hal: 285-327.

Buckman, H. O. dan N. C. Brady. 1982. Ilmu Tanah. Terjemahan Soegiman, Bhratara Karya Aksara, Jakarta.

Church, D.C. 1979. Digestive Physiology and Nutrition of Ruminant.Vol 2.Oxford Press.

De La Cruz, R. E. 1981. Mycorriza in alternative to energy-based in organic fertilizer. Paper presented in the PCARR, Manilla.

Fedrial, J. 2005. Pengaruh peningkatan takaran pemupukan $\mathrm{N}, \mathrm{P}$, dan $\mathrm{K}$ terhadap pertumbuhan dan produksi Rumput Benggala (Panicum maximum) pada Tanah PMK Pemotongan Pertama. Skripsi Fakultas Peternakan Universitas Andalas, Padang.

Husin, E. F. 2002. Respon berbagai tanaman terhadap pupuk hayati, cendawan mikoriza arbuskula Pusat Studi dan 
Pengembangan Agen Hayati (PUSPAHATI). UNAND, Padang.

Lakitan, B. 1993.Dasar-dasar Fisiologi Tumbuhan. P.T. Raya Grafindo Persada, Jakarta.

Read, D. J. 1999. Mycorrhiza-The State of the Art. P. 43-49 in A. Varma and B. Hock (eds) Mycorrizha: Strukture Function, Molekular Biology and Biotektologi. Springer-Verlang, Berlin.

Setiadi, Y. 1994 Mengenal mikoriza vecikularis arbuskula sebagai pupuk biologis untuk mereklamasi lahan kritis. Pusat Antar Universitas Bioteknologi Institut Pertanian Bogor, Bogor.

Sutardi, T. 1980. Ternak Perah dan Pemberian Makanannya.Edisi I Depertemen Ilmu Makanan Ternak. Fakultas Peternakan Institut Pertanian Bogor, Bogor.

Suyitman, dkk. 2003. Diktat Agrostologi. Fakultas Peternakan Universitas Andalas. Padang
Steel, R. G. D. and Torrie, J. H, 1991. Prinsip dan Prosedur Statistik Suatu Pendekatan Biometrik. Edisi ke-2, Alihbahasa, Bambang Sumantri. PT. Gramedia Pustaka Utama, Jakarta.

Tilley, J. M. and R. A. Terry. 1963. A Two Stage Technique ForIn-Vitro Digestion of Forage Crop. British Grassland.

Tisdale, S. L. And W. L. Nelson. 1975. Soil Fertility and Fertilitation. The Mac Millian Company Collien Mac Limited, London.

Ningsih, W. 2007. Pengaruh dosis pupuk N, P, dan $\mathrm{K}$ dan inokulasi CMA Glomus manihotis pada tanah ultisol rumput gajah (Pennisetum purpureum) cv. Taiwan pemotongan pertama terhadap kecernaan BK, BO, dan PK secara InVitro. Skripsi Fakultas Peternakan Universitas Andalas, Padang. 